\title{
Nitrogen Fertilizer Use Efficiency of Irradiated Mutant Rice
}

\author{
Ania Citraresmini*, M. Hanani, N. Robifahmi, I. Milyardi, T. Bachtiar, and N.A. \\ Flatian
}

Centre for Isotope and Radiation Application, National Nuclear Energy Agency, Jakarta, Indonesia, 12044, Corresponding author. Email: aniacitra@gmail.com

\begin{abstract}
The carrying capacity of rice plants to meet national food demand is inseparable from effective and efficient cultivation techniques. The need of rice plants for fertilizer is a recurring problem, due to the farmers' tendency to apply fertilizer, especially urea, at the excessive doses. Balanced fertilizer practice is currently a trend encouraged by the government, because the lands that receive intensive chemical fertilization rate decreased in its fertility and health. It is indicated by the low soil acidity value (tends to be acidic to acidic) and the low soil organic carbon (SOC) content $(<1 \%)$. This case happens in most areas of intensive rice cultivation in Indonesia. The principle of balanced fertilization is to provide a number of nutrients in accordance with the amount of plant needs. Determining the nutrients needed by plants can be done in several ways, including by knowing the efficiency level of plants in utilizing the nutrients that are given or added to the soil. The research objective was to determine the fertilizer dosage with the optimum efficiency level for lowland rice plants. The experiment was carried out in the rice fields of Muara Experimental Station, Bogor, using Batan's mutant rice variety and mutant line, and national rice variety as a comparison. Randomized Complete Block Design in factorial pattern was using in the experiment. As the first factor is rice variety, consisting of 3 levels factors: 1). Sidenuk mutant rice; 2). mutant line rice; and 3). Ciherang national rice variety. While the dose of urea as second factor consists of 4 levels: 1). no urea fertilizer; 2). urea at a dose of 100 $\mathrm{kg} \mathrm{N} /$ ha; 3). urea at a dose of $200 \mathrm{~kg} \mathrm{~N} / \mathrm{ha}$; and 4). urea at a dose of $300 \mathrm{~kg} \mathrm{~N} /$ ha. Stable isotope techniques ${ }^{15} \mathrm{~N}$ is used to determine the efficiency of nitrogen uptake by rice plants. The results showed that the highest nitrogen use efficiency of rice varieties owned by Sidenuk amounted to $22.76 \%$; Ciherang variety was $22.30 \%$; and the mutant lines were $17.19 \%$. This efficiency was obtained from the application of urea fertilizer at a dose of $100 \mathrm{~kg} \mathrm{~N} / \mathrm{ha}$ (Sidenuk and Ciherang) and $200 \mathrm{~kg} \mathrm{~N} /$ ha (mutant lines).
\end{abstract}

Keywords: Nitrogen use efficiency, Isotope stable ${ }^{15} \mathrm{~N}$, Lowland rice, Rice mutant, Sidenuk variety

\section{INTRODUCTION}

The main objective of agricultural development in Indonesia is to improve food self-sufficiency and increase farmers' welfare [1]. Self-sufficiency in rice achieved when the rice production can be met with the demand of national production, by increasing the number of production and/or expanding planting area. In order to increase rice yield, farmers often apply chemical fertilizer (especially urea) excessively in an intensive farming system. The behaviour of using urea fertilizer with increasing doses is due to government subsidies for the purchase of urea fertilizer for agriculture. This is in line with the objective of agricultural development program for increasing rice production intensively, as expanding productive planted area can not be fulfilled.
Urea fertilizer requirements increase every year, supported also by the use of superior rice varieties that are highly responsive to nutrients, especially nitrogen. Nowadays the tendency to apply excessive amounts of urea are still continue, ranging from 250 up to $500 \mathrm{~kg}$ urea per hectare of paddy land $(100-250 \mathrm{~kg} \mathrm{~N} / \mathrm{ha})$. According to the Indonesian Fertilizer Producer Association (IFPA) each year the need for subsidized urea fertilizer for agriculture increases by $6.11 \%$. Urea fertilizer consumption in 2017 became the largest in the last 10 years with an achievement of 5.97 million tons, dominated by the agricultural sector with absorption reaching 4.10 million tons, the plantation sector by 1.01 million tons, and industry by 847.000 tons [2]. 
The needs of urea based on the understanding that nitrogen is an essential nutrient for the optimum growth of plant, especially for food crops. It takes a role as an amino acid builder, which then become part of the protein and nucleic acid (DNA and RNA) [3,4]. Nitrogen is also part of the integral clorophyll, a light absorbance pigment in the photosynthesis system. Its availability has become a must, considering its important role to plant's growth and development. That's why an addition of nitrogen fertilizer is always needed. The abundance of nitrogen in plant tissue is relatively high, about $1-5 \%$ of plant dry mass.

Batan has produced 23 rice mutant varieties. The general description of each variety is high yield potential. Potential yield can be achieved if there is support from the growing environment and proper cultivation techniques. The growing environment must be able to provide nutrients for optimal plant growth, and cultivation techniques must support plants to achieve their potential yield.

In general, Batans' rice mutant variety is having high yield potency about 8-11 ton per hectar. This high yield potential is one of Batan's privileges in disseminating its innovative results to support national rice production. The ability of mutant superior rice varieties in utilizing nutrients is one of the information needed in an effort to disseminate the use of research and development result carried out by Batan.

A series of studies conducted to determine the ability of the Batan mutant rice variety to utilize nutrient nutrients. Through experiments, it can be determined how efficiently mutant rice varieties in absorbing nutrients, especially nitrogen, so that the need for and dependence on chemical fertilizers can be minimized.

\section{MATERIALS AND METHODS}

The experiment conducted in the Rice Exprimental Station Agriculture Research and Development BureauMinistry of Agriculture Muara, Bogor-West Java, Indonesia from October 2019 until January 2020. Rice plantation been done in the middle of rainy season. It was estimated that the generative stage will start at the end of the rainy season so that the harvest time will occur at the beginning of the dry season. Experiment was carried out by applying a factorial randomized block design. The first factor is 3 levels of rice mutant varieties: 1) Sidenuk; 2) Mutant Lines; 3) Ciherang (national variety). The second factor is 4 levels of urea doses: 1) No urea; 2) Urea dose of $100 \mathrm{~kg} \mathrm{~N} / \mathrm{ha}$; 3) Urea dose of $200 \mathrm{~kg} \mathrm{~N} / \mathrm{ha}$; 4). Urea dose of $300 \mathrm{~kg} \mathrm{~N} / \mathrm{ha}$.

Prior to the experiment, soil samples were taken for analysis of soil characteristics in the experimental field. Observation parameters include: soil characteristics, plant height, number of tillers, N-plant uptake, plant production, $\%{ }^{15} \mathrm{~N}$ plants and nitrogen uptake efficiency.

Ten days old germinated seed of mutant variety was planted in the middle of rainy season. Urea fertilizer as source of $\mathrm{N}$ was given in 3 steps : 1/3 first dose given at 7 days after planting, 1/3 second dose given at 30 days after planting, and the last $1 / 3$ dose given at 45 days after planting or near to vegetative maximum growth stadia.

Fertilizer SP-36 (as source of $\mathrm{P}$ ) and $\mathrm{KCl}$ (as source of $\mathrm{K}$ ), was given once at a time at 7 days after planting.

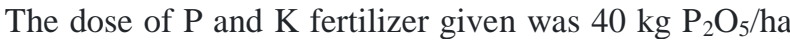
and $50 \mathrm{~kg} \mathrm{~K} \mathrm{~K}_{2} \mathrm{O} / \mathrm{ha}$, respectively. At the time of fertilization, the rice field condition is in a muddy state, indicated by water level up to $2 \mathrm{~cm}$. Stable isotope of ${ }^{15} \mathrm{~N}$ as a tracer was given in the form of labeled-urea of $2 \%$ atom excess. Urea ${ }^{15} \mathrm{~N}$ is applied to rice plants grown in the microplot of $1 \times 1 \mathrm{~m}^{2}$ size. The time of application had adjusted according to the level of $\mathrm{N}$ fertilizer treatment applied in the experiment.

\section{RESULTS AND DISCUSSION}

\subsection{Soil characteristic}

The soil analysis result is presented in Table 1. From the data in the table it can be shown that the soil is classified as slightly acid, with very low carbon organic content $(0.17 \%)$; low N-total content $(0,12 \%)$; and low $\mathrm{C} / \mathrm{N}$ ratio $(1,42)$. This condition is potential to cause the unavailability of $\mathrm{N}$ in the soil for plants, so that the level of additional $\mathrm{N}$ from fertilizer will be highly needed by plant.

Meanwhile the exchangeable-K status in the soil is categorized low, that will indirectly impacting to the nitrogen unavailability from fertilizer added. 
Table 1. Soil analysis characteristics from Muara-Bogor, West Java

\begin{tabular}{|c|c|c|c|c|}
\hline No & Parameters & Units & Value & Criteria *) \\
\hline 1. & $\mathrm{pH} \mathrm{H} \mathrm{H}_{2} \mathrm{O}(1: 2,5)$ & & 6.23 & Slightly acid \\
\hline 2. & $\mathrm{pH} \mathrm{KCl} 1 \mathrm{~N}(1: 2,5)$ & & 5.65 & Slightly acid \\
\hline 3. & C-Organic & $\%$ & 0.17 & Very low \\
\hline 4. & $\mathrm{~N}$-total & $\%$ & 0.12 & Low \\
\hline 5. & $\mathrm{C} / \mathrm{N}$ ratio & & 1.42 & Very low \\
\hline 6. & $\mathrm{P}_{2} \mathrm{O}_{5}$ available & $\mathrm{mg} \mathrm{kg}^{-1}(\mathrm{ppm})$ & 199.47 & Very high \\
\hline 7. & $\mathrm{SiO}_{2}$ available & $\mathrm{mg} \mathrm{kg}^{-1}$ & 291 & Low \\
\hline 8. & $\mathrm{P}_{2} \mathrm{O}_{5}$ potential & $\mathrm{mg} 100 \mathrm{~g}^{-1}$ & 953.63 & Very high \\
\hline 9. & $\mathrm{~K}_{2} \mathrm{O}$ potential & $\mathrm{mg}^{100 \mathrm{~g}^{-1}(\mathrm{ppm})}$ & 12.55 & Low \\
\hline 10. & K-exchangeable & 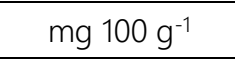 & 10.18 & Low \\
\hline \multirow[t]{5}{*}{11.} & Exchangeable cations & & & \\
\hline & $\mathrm{K}^{+}$ & $\mathrm{cmol} \mathrm{kg}^{-1}$ & 0.13 & Low \\
\hline & $\mathrm{Na}^{+}$ & $\mathrm{cmol} \mathrm{kg}^{-1}$ & 0.11 & Medium \\
\hline & $\mathrm{Ca}^{2+}$ & $\mathrm{cmol} \mathrm{kg}^{-1}$ & 11.58 & High \\
\hline & $\mathrm{Mg}^{2+}$ & $\mathrm{cmol} \mathrm{kg}^{-1}$ & 0.64 & Low \\
\hline 12. & Al-dd & $\mathrm{cmol} \mathrm{kg}^{-1}$ & $<0.05$ & \\
\hline 13. & $\mathrm{H}-\mathrm{dd}$ & $\mathrm{cmol} \mathrm{kg}^{-1}$ & 0.10 & \\
\hline 12. & KTK & $\mathrm{cmol} \mathrm{kg}^{-1}$ & 19.60 & Medium \\
\hline 13. & Base Saturation & $\%$ & 63.56 & High \\
\hline \multirow[t]{4}{*}{14.} & Texture : & & & \\
\hline & Sand (\%) & $\%$ & 19.70 & \\
\hline & Silt (\%) & $\%$ & 28.20 & \\
\hline & Clay (\%) & $\%$ & 52.02 & \\
\hline
\end{tabular}

Cation exchange capacity is classified to moderate, indicating that the bases are could not be held by soil colloid surface so that the bases are not available to plants because they are not interchangeable. This condition is in line with the exchangeable-K nutrient status, which is in a low level. As a substitution ion, the presence of this element in the exchange site is at a low level so that it does not allow exchange with other bases. This situation describes the number of bases dissolved in the soil solution and causes a high base saturation value. It characterizes the rate of leaching or weathering nutrients in the soil, which identifying low and even very low soil fertility. With these soil characteristics, additional nutrient from fertilizer is needed.

\subsection{Agronomic data}

\subsubsection{Plant height}

Plant height showed an independent response to the treatment, neither to the different varieties nor to nitrogen doses. The data in the Table 2 shows the independent response of plant height upon plant varieties. The highest plant height is shown by Sidenuk variety, which is significantly different to other varities. Plant description of Sidenuk variety shows, that its height reaches $100 \mathrm{~cm}$ per plant. In this experiment the plant height almost reached its potential height. Each plant variety has its own characteristic related to plant height, environmental support is able to encourage plants to reach the potential of these characteristics. 
Table 2. Independent effect of plant varieties on the response of plant height

\begin{tabular}{l|c|}
\hline \multicolumn{1}{|c|}{ Variety } & Plant height (cm) \\
\hline Sidenuk (V1) & $85.37 \mathrm{aa}$ \\
\hline Galur mutan (V2) & $78.56 \mathrm{~b}$ \\
\hline Ciherang (V3) & $76.99 \mathrm{c}$ \\
\hline $\begin{array}{l}\text { a the different letter in the vertical direction shows a } \\
\text { significantly different response in Duncan's test at 5\% } \\
\text { level }\end{array}$
\end{tabular}

As stated by [5] that plant performance is the result of genetic interaction with environmental factors. In this case, plant height influenced more by environmental conditions to grow. The soil used in the experiment had very high levels of available-P and very high potential-P, that presumably available at the beginning of plant growth. The role of element $\mathrm{P}$ for plants is as the main nutrient in the growth and development of plant cells, especially for meristematic cells. This element has become a critical factor for plant growth, because very needed even in very small amounts by plants [6]. In this case, it seems that Sidenuk, as mutan rice variety, is more responsive to the nutrient availability, compare to other varieties.

The response of plant height varies according to the description of each variety and line. Application of nitrogen fertilizer at various doses also causes differences in plant height, with a tendency that the higher the nitrogen dose, the higher the plant growth. Independent effect of both types of treatment (variety and nitrogen doses) showed that nitrogen fertilization could stimulate plant height increase, but did not change the plant height potential of each variety.

Table 3. Independent effect of nitrogen doses on the response of plant height

\begin{tabular}{|c|c|}
\hline N fertilizer doses & Plant height $(\mathrm{cm})$ \\
\hline N0 & $70.10 \mathrm{aa}$ \\
\hline N1 & $78.52 \mathrm{~b}$ \\
\hline N2 & $84.23 \mathrm{c}$ \\
\hline N3 & $88.38 \mathrm{~d}$ \\
\hline
\end{tabular}

${ }^{a}$ the different letter in the vertical direction

shows a significantly different response in

Duncan's test at 5\% level

The difference in plant height in each plant was very significant along with the increase in the nitrogen dose received. This also shows that the plants respond very well to the given nitrogen element, due to the low nitrogen content in the soil $(0,12 \%$ N-total soil in (Table 1$)$. Currie and Perry [7] stated that lowland rice is always responsive to fertilization given to it. In conditions of nitrogen unavailability in the soil, plants become very responsive to additional nutrients from fertilizer.

In a paddy field, $\mathrm{N}$ elements are widely exchanged in the form of $\mathrm{NH}_{4}{ }^{+}$due to the presence of a waterlogged layer. Brady and Weil [8] stated that one of the impacts of flooding on paddy fields is a change in the electrochemical properties of the soil, namely a decrease in redox potential (Eh), which causes a decrease in $\mathrm{NO}_{3}{ }^{-}$but increases the accumulation of $\mathrm{NH}_{4}^{+}$and nitrogen fixation. Correspondingly, Mulyani et al [9] stated that the form of ammonium ion $\left(\mathrm{NH}_{4}{ }^{+}\right)$is a form that can be easily absorbed by plants, especially in plants fertilized with urea $\left(\mathrm{CO}\left(\mathrm{NH}_{2}\right)_{2}\right)$ where the $\mathrm{N}$ form is very soluble in water and react quickly. In this study, it was assumed that the inundation conditions and the application of urea fertilizer became a favourable growing environment for rice plants, although the total $\mathrm{N}$ content of the soil was low.

\subsubsection{Tiller numbers}

The number of tillers formed also indicated plant growth parameters. According to Endrizal and Bobihoe [10] and Iqbal [11] the growth and development of the number of tillers is strongly influenced by the adequacy of nitrogen at the beginning of growth, and this element supports the plant phenotype of its genotype potential in forming tillers. This condition is evident in the data obtained, the data from statistical analysis shows an interaction between varieties and the dose of nitrogen fertilization on the response to the number of tillers.

Table 4. Interaction effect of plant varieties and nitrogen doses on the response of tiller numbers

\begin{tabular}{|c|c|c|c|c|}
\hline \multirow{2}{*}{ Varieties } & \multicolumn{4}{|c|}{ Nitrogen doses } \\
\cline { 2 - 5 } & N0 & N1 & N2 & N3 \\
\hline V1 & $19.07 \mathrm{a}^{\mathrm{a}}$ & $22.40 \mathrm{a}$ & $24.53 \mathrm{a}$ & $26.60 \mathrm{a}$ \\
& $\mathrm{A}^{\mathrm{b}}$ & $\mathrm{B}$ & $\mathrm{B}^{\mathrm{C}}$ & $\mathrm{C}$ \\
\hline V2 & $20.87 \mathrm{a}$ & $27.87 \mathrm{~b}$ & $27.87 \mathrm{~b}$ & $35.33 \mathrm{~b}$ \\
& $\mathrm{~A}$ & $\mathrm{~B}$ & $\mathrm{~B}$ & $\mathrm{C}$ \\
\hline V3 & $22.07 \mathrm{a}$ & $23.27 \mathrm{a}$ & $29.47 \mathrm{~b}$ & $29.07 \mathrm{a}$ \\
& $\mathrm{A}$ & $\mathrm{A}$ & $\mathrm{B}$ & $\mathrm{B}$ \\
\hline
\end{tabular}

${ }^{a}$ The different letter in the vertical direction shows a significantly different response in Duncan's test at 5\% level

${ }^{\mathrm{b}}$ The different letter in the horisontal direction shows a significantly different response in Duncan's test at $5 \%$ level

The data in the table above shows that the number of tillers in each variety generally increased with 
increasing nitrogen dose. However, statistically, the treatment without nitrogen on the Ciherang variety (V3, national variety) showed the same number of tillers as compared to the Ciherang variety which received a nitrogen dose of $100 \mathrm{~kg} \mathrm{~N} / \mathrm{ha}(\mathrm{N} 1)$. This condition explains the support of growing environmental factors on the genotype potential of the number of tillers in the variety, so that a high number of tillers is obtained.

High saturation base (KB) in the soil is indicating the number of available bases in the soil. As the CEC (KTK) of the soil classified as low (see Table 1) it can be concluded that the cation base is in the free form, which can be easily leached from the soil solution. The existence of cultivated plant in the soil has given a strong bonding to the free cation bases and decreasing its risk from being leached. Thus the plant gained the benefit from its existence in the free form by easily absorb the $\mathrm{NH}_{4}{ }^{+}$as the source of nitrogen.
When urea fertilizers are surface applied or incorporated into low CEC soils (particularly if incorporated to shallow depths), this reaction often continues to form $\mathrm{NH}_{3}$ and $\mathrm{CO}_{2}$. However, in paddy fields there is a layer of flooded soil, where in the flooded conditions the availability of $\mathrm{NH}_{4}{ }^{+}$increases and this form is more stable under anaerobic conditions [12]. High base saturation $(63,56 \%$, see Table 1) in this soil indicates the availability of a number of bases. The presence of plants provides a strong bond to these bases, so that the Kexchangeable elements not leached and still able to play a role in the exchange of $\mathrm{NH}_{4}{ }^{+}$from the soil solution into the plant body.

The main purpose of applying $\mathrm{N}$ fertilizer is to increase dry matter. Dry matter is a form of photosyntate accumulation in plants, which describes the results of the absorption of nitrogen nutrients. The response of dry weight of straw and dry weight of grain in this study showed an independent effect on each treatment (variety and nitrogen dose), not an interaction between the two treatments.

\subsubsection{Plants dry weight and nitrogen content}

Table 5. Independent effect of plant varieties on the response of straw and grain dry weight and nitrogen content

\begin{tabular}{|c|c|c|c|c|}
\hline Varieties & $\begin{array}{c}\text { Dry weight straw } \\
\text { (ton/ha) }\end{array}$ & $\begin{array}{c}\text { Straw N content } \\
\text { (kg/ha) }\end{array}$ & $\begin{array}{c}\text { Dry weight grain } \\
\text { (ton/ha) }\end{array}$ & Grain N content (kg/ha) \\
\hline V1 & $3.49 \mathrm{aa}$ & $19.34 \mathrm{a}$ & $5.40 \mathrm{a}$ & $58.67 \mathrm{a}$ \\
\hline V2 & $3.69 \mathrm{a}$ & $21.11 \mathrm{a}$ & $5.14 \mathrm{a}$ & $56.94 \mathrm{a}$ \\
\hline V3 & $3.70 \mathrm{a}$ & $16.19 \mathrm{a}$ & $4.72 \mathrm{a}$ & $49.3 \mathrm{a}$ \\
\hline
\end{tabular}

${ }^{a}$ the different letter in the vertical direction shows a significantly different response in Duncan's test at 5\% level

Data in the table above shows that different rice varieties did not affect dry weight of straw and grain, and its nitrogen content. Growing environmental conditions with $\mathrm{pH}$ values tend to be neutral, causing nutrient solubility to be maintained, especially nitrogen nutrients in the form of $\mathrm{NH}_{4}{ }^{+}$. Rice plants have an aerenchyma in their roots so that when ammonium oxidized into nitrite it will immediately be oxidized into nitrate, which can also be utilized by rice plants [13]. Presumably this is the reason why rice plants in various varieties show the same response of straw and grain dry weight and nitrogen content.

Table 6. Independent effect of nitrogen doses on the response of straw and grain dry weight and nitrogen content

\begin{tabular}{|c|c|c|c|c|}
\hline $\begin{array}{c}\text { N fertilizer } \\
\text { doses }\end{array}$ & $\begin{array}{c}\text { Dry weight straw } \\
\text { (ton/ha) }\end{array}$ & $\begin{array}{c}\text { Straw N content } \\
(\mathrm{kg} / \mathrm{ha})\end{array}$ & $\begin{array}{c}\text { Dry weight grain } \\
\text { (ton/ha) }\end{array}$ & $\begin{array}{c}\text { Grain N content } \\
(\mathrm{kg} / \mathrm{ha})\end{array}$ \\
\hline N0 & $1.21 \mathrm{a}$ & $5.48 \mathrm{a}$ & $3.77 \mathrm{a}$ & $29.92 \mathrm{a}$ \\
\hline N1 & $3.89 \mathrm{~b}$ & $16.62 \mathrm{~b}$ & $5.12 \mathrm{~b}$ & $52.19 \mathrm{~b}$ \\
\hline N2 & $4.51 \mathrm{bc}$ & $24.52 \mathrm{bc}$ & $5.42 \mathrm{bc}$ & $63.28 \mathrm{bc}$ \\
\hline N3 & $4.89 \mathrm{c}$ & $28.91 \mathrm{c}$ & $6.04 \mathrm{c}$ & $74.48 \mathrm{c}$ \\
\hline
\end{tabular}

${ }^{a}$ the different letter in the vertical direction shows a significantly different response in Duncan's test at 5\% level 
Data in the table above shows that different doses of nitrogen affect dry weight of straw and grain, and its nitrogen content. In this case, the highest nitrogen dose still received an uptake response by plants due to the low N-total content of the soil. Erisman et al [14] stated the results of their research that superior rice varieties were very responsive to $\mathrm{N}$ and $\mathrm{P}$ fertilization, especially in the soil with low content of $\mathrm{N}$ and $\mathrm{P}$. The increase in dry weight of straw and grain occurred along with the increase dose of nitrogen given. Statistically, the dose of nitrogen in $200 \mathrm{~kg} \mathrm{~N} / \mathrm{ha}(\mathrm{N} 2)$ is given the same dry weight of straw and grain and nitrogen content with the one that given nitrogen in the dose of $300 \mathrm{~kg} \mathrm{~N} / \mathrm{ha}(\mathrm{N} 3)$. In general, an increase in nitrogen dose led to an increase in dry weight and $\mathrm{N}$ content in plants. The highest dose of nitrogen (300 kg N/ha) significantly increased dry weight of straw and grain, and its total$\mathrm{N}$ content.

\subsubsection{Nitrogen derived from various sources}

The stable isotope ${ }^{15} \mathrm{~N}$ tracing technique was used to describe the origin of nitrogen inside plants body and to determine how efficiently the nitrogen dose used by plant to support its growth. In this study, the ${ }^{15} \mathrm{~N}$ isotope technique was used to determine percentage of the nitrogen element from urea fertilizer that utilized by plants. This technique also used to determine efficiency use of nitrogen from fertilizers at each nitrogen doses given.

Tracing with the stable isotope ${ }^{15} \mathrm{~N}$ technique in this study provides a real picture, whether the nitrogen content that forms the dry matter of this plant comes from the nitrogen fertilizer given or comes from the soil. The data of N-total straw and Ntotal grain in Table 6 can be broken down into $\mathrm{N}$ content from fertilizers and $\mathrm{N}$-content from soil in straw and grain. Data of plant-N derived from various sources of $\mathrm{N}$ can be seen in Table 7 .

Table 7. Independent effect of plant varieties on the response of $\mathrm{N}$-derived from various source

\begin{tabular}{|c|c|c|c|c|}
\hline Varieties & $\begin{array}{c}\text { N-dffa in straw } \\
(\mathrm{kg} / \mathrm{ha})\end{array}$ & $\begin{array}{c}\text { N-dfsb in straw } \\
(\mathrm{kg} / \mathrm{ha})\end{array}$ & $\begin{array}{c}\text { N-dff in grain } \\
(\mathrm{kg} / \mathrm{ha})\end{array}$ & $\begin{array}{c}\text {-dfs in grain } \\
(\mathrm{kg} / \mathrm{ha})\end{array}$ \\
\hline V1 & $7.04 \mathrm{ac}$ & $12.30 \mathrm{a}$ & $14.61 \mathrm{a}$ & $44.06 \mathrm{a}$ \\
\hline V2 & $8.19 \mathrm{a}$ & $12.92 \mathrm{a}$ & $14.71 \mathrm{a}$ & $42.23 \mathrm{a}$ \\
\hline V3 & $6.07 \mathrm{a}$ & $10.13 \mathrm{a}$ & $13.25 \mathrm{a}$ & $36.05 \mathrm{a}$ \\
\hline
\end{tabular}

a N-dff $=\mathrm{N}$-derived from fertilize

$\mathrm{b} \mathrm{N}-\mathrm{dfs}=\mathrm{N}$-derived from soil

$\mathrm{c}$ the different letter in the vertical direction shows a significantly different response in Duncan's test at $5 \%$ level

The table above shows that percentage of $\mathrm{N}$ from soil is always higher than the percentage of $\mathrm{N}$ that comes from fertilizers. Tisdale et al [15] states that nitrogen is widely available in the atmosphere, reaching $78 \%$ of plant needs, therefore plants will first use the nitrogen source from soil that is fixated from the atmosphere. The presence of nitrogen in plant tissues is about $2-4 \%$ of the dry weight, and the levels vary according to environmental conditions of growth. Statistically, there was no difference in responses between plant varieties in the fractionation of $\mathrm{N}$ from soil and $\mathrm{N}$ from fertilizers. In this case, it is assumed that all varieties used have the same ability to utilize $\mathrm{N}$ from sources in their growing environment. Experimental soil used in this study had a high clay content $(52.02 \%$ see Table 1$)$ so that the nitrogen from fertilizer was absorbed by the soil and became available to plants. Soil $\mathrm{pH}$ conditions, which tend to be neutral, also support the availability of $\mathrm{N}$ in the form of $\mathrm{NO}_{3}{ }^{-}$for plants. Saraswati et al [14] stated that soil $\mathrm{pH}$ plays a role in the rate of nitrification of nitrogen in the soil, where at $\mathrm{pH}>5$ there will be a faster nitrification potential. 
Table 8. Independent effect of nitrogen doses on the response of $\mathrm{N}$-derived from various source

\begin{tabular}{|c|c|c|c|c|}
\hline N fertilizer doses & $\begin{array}{c}\mathrm{N} \text {-dffa in straw } \\
(\mathrm{kg} / \mathrm{ha})\end{array}$ & $\begin{array}{c}\mathrm{N} \text {-dfsb in straw } \\
(\mathrm{kg} / \mathrm{ha})\end{array}$ & $\begin{array}{c}\mathrm{N} \text {-dff in grain } \\
(\mathrm{kg} / \mathrm{ha})\end{array}$ & $\begin{array}{c}\mathrm{N} \text {-dfs in grain } \\
(\mathrm{kg} / \mathrm{ha})\end{array}$ \\
\hline $\mathrm{N} 0$ & $0.00 \mathrm{ac}$ & $5.48 \mathrm{a}$ & $0.00 \mathrm{a}$ & $29.92 \mathrm{a}$ \\
\hline $\mathrm{N} 1$ & $5.94 \mathrm{~b}$ & $10.68 \mathrm{ab}$ & $13.47 \mathrm{~b}$ & $38.71 \mathrm{ab}$ \\
\hline $\mathrm{N} 2$ & $9.09 \mathrm{bc}$ & $15.43 \mathrm{~b}$ & $17.64 \mathrm{~b}$ & $45.64 \mathrm{~b}$ \\
\hline $\mathrm{N} 3$ & $13.36 \mathrm{c}$ & $15.54 \mathrm{~b}$ & $25.64 \mathrm{c}$ & $48.85 \mathrm{~b}$ \\
\hline
\end{tabular}

${ }^{\mathrm{a}} \mathrm{N}$-dff $=\mathrm{N}$-derived from fertilizer

${ }^{\mathrm{b}} \mathrm{N}$-dfs $=\mathrm{N}$-derived from soil

${ }^{\mathrm{c}}$ the different letter in the vertical direction shows a significantly different response in Duncan's test at $5 \%$ level

Data in the table above shows an increase in the contribution of $\mathrm{N}$ from the fertilizer and from the soil when the nitrogen fertilizer dose is increased. The highest nitrogen dose $(300 \mathrm{~kg} \mathrm{~N} / \mathrm{ha}=\mathrm{N} 3)$ had the highest impact on $\mathrm{N}$ content from fertilizers and from soil compared to other nitrogen doses. In general, the $\mathrm{N}$ contribution from soil is greater than $\mathrm{N}$ contribution from fertilizers. In the treatment with no nitrogen fertilization (N0), it shows that nitrogen from the soil was able to meet the needs of plants from the vegetative part (straw) to the generative part (grain). Furthermore, the value of $\mathrm{N}$ content from soil was not significantly different from the nitrogen fertilization treatment at a dose of $100 \mathrm{~kg} \mathrm{~N} / \mathrm{ha}(\mathrm{N} 1)$.
As in the previous explanation, the experimental soil conditions which had a high clay content and a normal $\mathrm{pH}$ tended to help encourage the fulfilment of plant $\mathrm{N}$ needs even though the total $\mathrm{N}$ content of the soil was low. Nitrogen content in the straw is always shown lower than $\mathrm{N}$ content in the grain, indicated that nitrogen was well distributed from vegetative part (straw) to the generative part (grain) of the plant.

As a brief explanation, it can be seen in Figure 1, that the nitrogen content in plants consists of various nitrogen originating from various sources that can be absorbed by plants. The absorbed nitrogen is then distributed into the vegetative and generative parts of the plant.

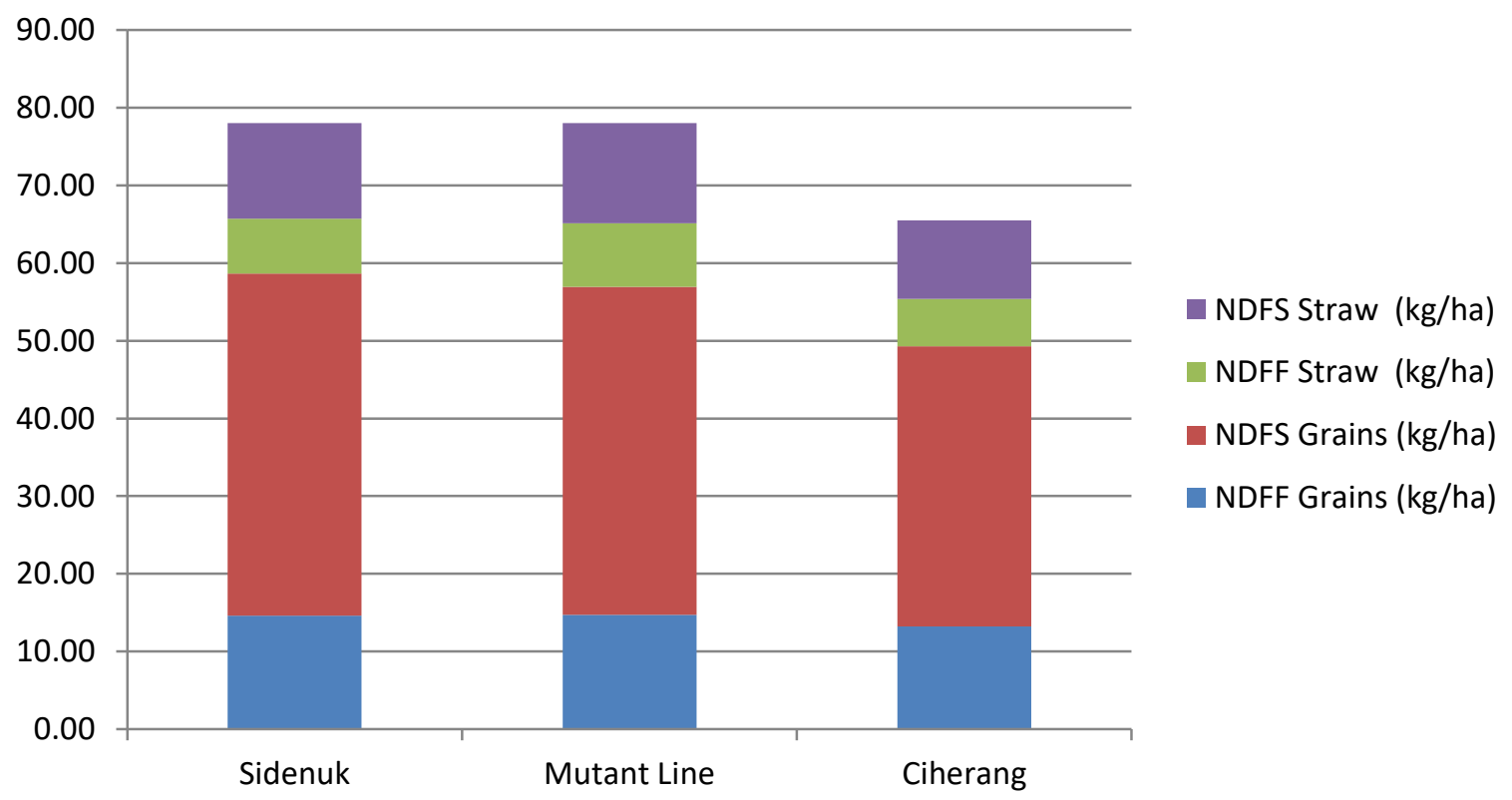

Figure 1. Distribution of nitrogen from fertilizers and from soil in vegetative and generative parts of three varieties of rice plants 
Total nitrogen content in plant is the sum amount of $\mathrm{N}$-content in straw added by $\mathrm{N}$-content in grain. The value gained from this calculation is then stated as $\mathrm{N}$-yield ( $\mathrm{kg} / \mathrm{ha})$. From the picture above, it can be seen that the highest $\mathrm{N}$-yield of plants is owned by the Sidenuk variety (V1). These data describe the ability of plant metabolism to absorb and distribute nitrogen obtained from various nitrogen sources in the soil, into parts of the plant body. This data also provides information that plants will use more nitrogen from the soil, compared to nitrogen from fertilization. However, fertilization is needed to create conditions of chemical balance in the soil solution, so that the movement of nutrients occurs towards the exchange site between clay colloids and plant roots [16].

\subsubsection{Nitrogen use efficiency}

The nitrogen efficiency obtained from the treatment of various doses of nitrogen in several varieties of rice can be calculated using plant $\mathrm{N}$-yield from fertilizer data $(\mathrm{kg} \mathrm{N} / \mathrm{ha})$ compared to the dose of $\mathrm{N}$ fertilizer applied to the soil. This data is very useful to determine efficient fertilizing doses for plants so that there is no wasteful use of fertilizer. Calculation results of nitrogen use efficiencies in this study are presented in the following table.

Table 9. Independent effect of plant varieties and nitrogen doses on the response of nitrogen use efficiency

\begin{tabular}{|c|c|c|c|}
\hline & NUEa Straw (\%) & NUE Grain (\%) & NUE Plants (\%) \\
\hline Varieties & & & \\
\hline V1 & $3.56 \mathrm{ab}$ & $8.35 \mathrm{a}$ & $11.91 \mathrm{a}$ \\
\hline V2 & $4.32 \mathrm{a}$ & $8.01 \mathrm{a}$ & $12.33 \mathrm{a}$ \\
\hline V3 & $3.33 \mathrm{a}$ & $6.77 \mathrm{a}$ & $10.10 \mathrm{a}$ \\
\hline Nitrogen doses & & & $0.00 \mathrm{a}$ \\
\hline N0 & $0.00 \mathrm{a}$ & $0.00 \mathrm{a}$ & $19.42 \mathrm{c}$ \\
\hline N1 & $4.46 \mathrm{~b}$ & $13.47 \mathrm{c}$ & $13.37 \mathrm{~b}$ \\
\hline N2 & $4.55 \mathrm{~b}$ & $8.82 \mathrm{~b}$ & $13.00 \mathrm{~b}$ \\
\hline N3 & $4.46 \mathrm{~b}$ & $8.55 \mathrm{~b}$ & \\
\hline
\end{tabular}

${ }^{a} \mathrm{NUE}=$ Nitrogen Use Efficiency

${ }^{\mathrm{b}}$ the different letter in the vertical direction shows a significantly different response in Duncan's test at $5 \%$ level

Statistically, the efficiency of nitrogen use is not affected by plant varieties. All varieties have the same ability to utilize nitrogen from fertilization, this is thought to be due to soil conditions that have low total $\mathrm{N}$ content so that plants respond very well to given fertilization. As stated by Tan [16], that fertilization plays a role in promoting chemical balance in the cation exchange area so that the movement of nutrients from the soil solution into the plant body occurs.

The dose of nitrogen fertilization showed its effect toward nitrogen uptake by plants. Nitrogen fertilization at a dose of $100 \mathrm{~kg} \mathrm{~N} / \mathrm{ha}$ gave the highest fertilization efficiency value compared to nitrogen fertilization at a dose of 200-300 kg N/ha. This shows that plants cannot always utilize the increasing dose of nitrogen. In this study, soil conditions with low total $\mathrm{N}$ content $(0.12 \%)$ made plants respond faster to $\mathrm{N}$ fertilization given in low doses (100 kg N/ha) compared to other doses (200 kg N/ha and $300 \mathrm{~kg} \mathrm{~N})$.
It can be seen in Table 8 that for all doses of nitrogen fertilizer, the contribution of nitrogen from the soil was much greater than the contribution of nitrogen from fertilizers. Allegedly, this is in line with the opinion of Tan [16] that the application of fertilizer into the soil has encouraged the principle of equilibrium, where fertilizers containing higher $\mathrm{N}$ have impregnating $\mathrm{N}$ in the soil solution and push it to enter the exchange site. Research findings of Citraresmini et al [17] and Bachtiar et al [18], also showed the same thing where the fractionation of $\mathrm{N}$ derived from various sources showed a larger contribution of $\mathrm{N}$ from the soil compared to $\mathrm{N}$ from other sources in the soil.

The graph below illustrates how those three rice varieties using nitrogen from various doses of nitrogen fertilizer. It can be seen that the most efficient use of nitrogen is coming from Sidenuk variety (V1) at the dose of $100 \mathrm{~kg} \mathrm{~N} / \mathrm{ha}$. The mutant line is following at the same dose of nitrogen $(100 \mathrm{~kg}$ 
$\mathrm{N} / \mathrm{ha}$ ), it seems that this mutant line potentially efficient in using nitrogen fertilizer as the parental
(Sidenuk variety). For the national variety, the most efficient use of nitrogen is $200 \mathrm{~kg} \mathrm{~N} / \mathrm{ha}$.

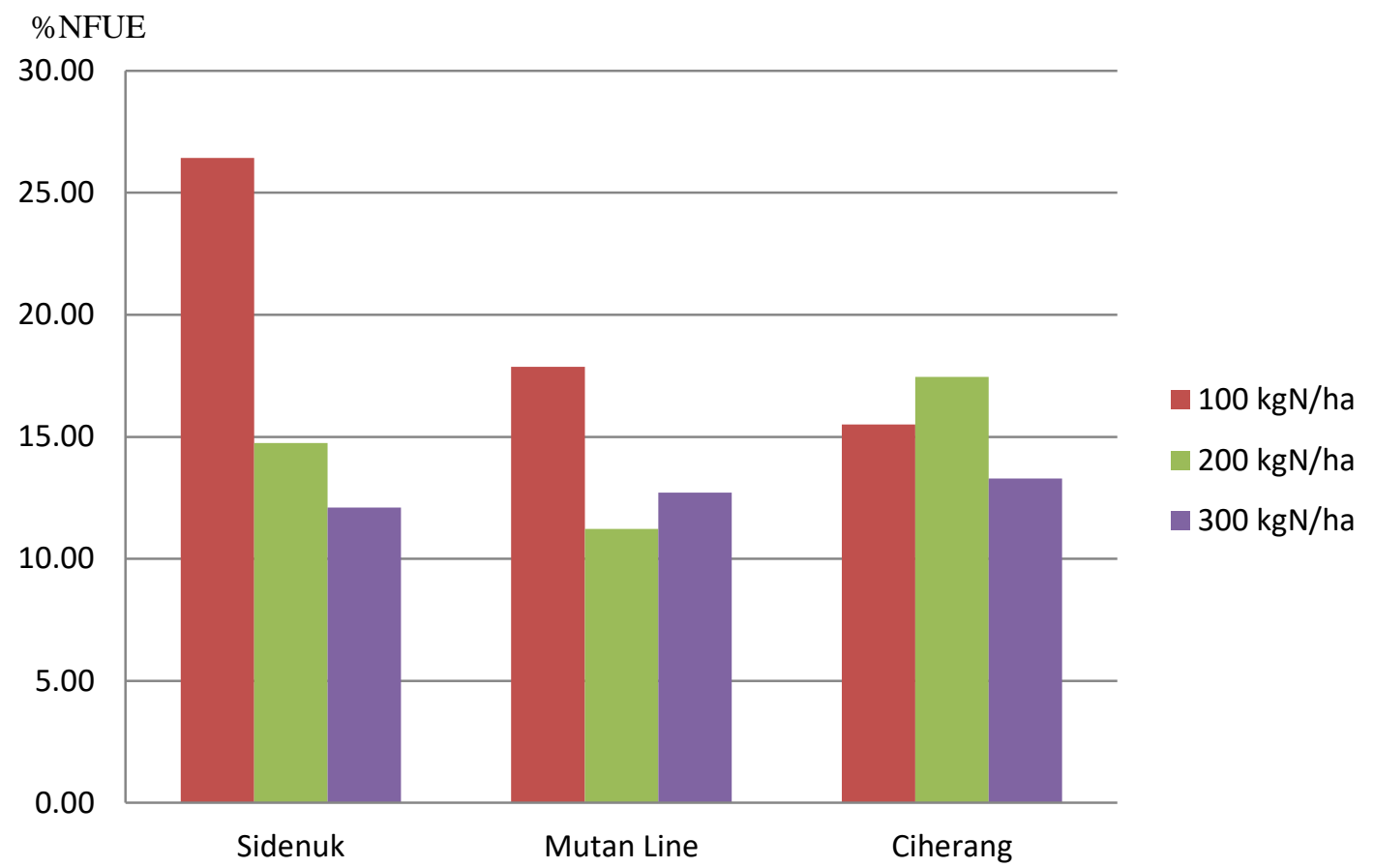

Figure 2 Efficient use of nitrogen by three rice varieties at the various doses of nitrogen fertilizer

From the results of tracing with the stable isotope technique of ${ }^{15} \mathrm{~N}$, it can be underlined that fertilizer is applied to the soil to meet the principle of nutrient balance in the soil, where nutrients from high concentrations will lead to nutrients with low concentrations. Thus, the exchange of nutrients occurs from the soil solution into the plant body. This is explaining why plants get more nitrogen from the soil. It is also an indication that nitrogen fertilization should be given in an amount that suits the needs of the plant.

\section{CONCLUSION}

Determination of nitrogen use efficiency by using stable isotope technique $\mathrm{N}-15$ shows that plants use more nitrogen from the soil, compared to nitrogen from fertilizers. Nitrogen fertilizer dose of $100 \mathrm{~kg} \mathrm{~N} / \mathrm{ha}$ is the suitable dose for lowland rice, which shows the highest efficiency (19.42\%) compared to other nitrogen fertilization doses. Sidenuk mutant rice variety is the most efficient in using nitrogen from fertilizer.

\section{ACKNOWLEDGMENT}

We would like to thank Sudono Slamet, SP as the field coordinator in conducting research and laboratory analysis.

\section{REFERENCES}

[1] F. Wardani, A., Dj. Hartono, and A. Alam Awirya. 2013. Determinants of Agricultural Food Crops Land Productivity in Indonesia. $J$. Ekonomi Pembangunan Vol. 14 (1), June 2013 : 110-125

[2] Indonesian Fertilizer Producer Association. 2018. The Increasement of Fertilizer Consumption.

https://kemenperin.go.id/artikel/20500/Konsu msi-Pupuk-Kian-Menanjak

[3] McGrath JM, Spargo J, and Penn CJ. 2014. Soil Fertility and Plant Nutrition. Encyclopedia of Agriculture and Food Systems. 5: 166-184 
[4] Gu J, Li Z, Mao Y, Struik PC, Zhang H, Liu L, and Yang J. 2018. Roles of Nitrogen and Cytokinin Signals in Root and Shoot Communications in Maximizing of Plant Productivity and Their Agronomic Applications. Plant Science 274: 320-331.

[5] Crowder, C.V. 1997. Plant Genetics. Translation to Indonesia by Lilik Kusdiarti. Gajah Mada University Press. Yogyakarta. $499 \mathrm{pp}$

[6] Gardner, F.P., R.B. Pearce and R.L. Mithcehell. 1985. Plant Crop Physiology. Translation to Indonesia by Herawati. 1991. Universitas Indonesia Press. Jakarta .728 pp

[7] Currie, H.A., dan C.C. Perry. 2007. Silica in Plants: Biological, Biochemical and Chemical Studies. Ann. of Botany 100: 1383-1389.

[8] Brady, N. C. and R. R, Weil. 2002. The Nature and Properties of Soils. Thirteenth Edition. Pearson Education, Inc. Upper Saddle River, New Jersey. 960 pp

[9] N.S. Mulyani, M.E. Suryadi, S. Dwiningsih and Haryanto. 2001. Nitrogen Dynamics on Rice Field Soils. J. Tanah dan Iklim (19) 2001 :14-25

[10] Endrizal and J. Bobihoe. 2004. Efficient Use of Nitrogen Fertilizer by Using Organic Fertilizer for Lowland Soil. J. Pengkajian dan Pengembangan Teknologi PertanianI 7(2):118-124

[11] Iqbal, A. 2008. Pertumbuhan dan Hasil Padi Sawah dengan Penggunaan Macam Pupuk Organik dan Dosis Pupuk Nitrogen. Agrivita $30: 371-379$
[12] Hardjowigeno and Reyes. 2015. Lowland Soil : Characteristics, Condition and Constraint of Lowland Soil in Indonesia. Bayumedia Publishing. Malang. 205 pp

[13] Chain Jan Willem Erisman, Allison Leac, Albert Bleeker, Brooke Atwell, Lia Cattaneo and James Galloway, 2018. An Integrated Approach to a Nitrogen Use Efficiency (NUE) Indicator for the Food ProductionConsumption Chain, Sustainability 10, 925; doi:10.3390/su10040925

[14] Saraswati, R. Ratih D. Hastuti, Erny Yuniarti, Jati Purwani, Elsanti. 2007. Pengembangan Teknologi Mikroflora Tanah Multiguna untuk Efisiensi Pemupukan dan Keberlanjutan Produktivitas Lahan Pertanian. Laporan Akhir Tahunan. 2007. (unpublished) Jurnal Mikrobiologi Indonesia Vol. 4(1) :1-9

[15] Tisdale, S.L., Nelson, W.L. and Beaton, J.D. 1985. Soil Fertility and Fertilizers. 4th Edition, Macmillan Publishing Company, New York. $784 \mathrm{pp}$

[16] Tan, K.H. 1998. Principles of Soil Chemistry. 3rd Ed. Marcel Decker, Inc. New York, Basel, Hong Kong. 295 pp

[17] A. Citraresmini, H. Halim and E.L. Sisworo. 2012. Measuring the BNF of Soybean Using $15 \mathrm{~N}$-Labelled Urea with Different Atom Excess (A.E.) Content. J. Atom Indonesia Vol. 38 No. 3 (2012) : 131-137

[18] T. Bachtiar, Nurrobifahmi, A. Citraresmini and A.N. Flatian. 2019. The Use of $15 \mathrm{~N}$ Isotope Technique to Evaluate the Impact of Biochar and Nitrogen Fixing Bacteria on Nitrogen Uptake by Rice. J. Tanah dan Iklim Vol. 43 No. 2, Desember 2019: 139-145 